\title{
Severe imported malaria in a Brazilian non-endemic region: a permanent alert for travelers and health teams
}

\section{Malária grave importada em região não endêmica brasileira: um alerta permanente para viajantes e equipes de saúde}

Matheus Dias Girão Rochaํ. Evelyne Santana Girão². Janete Romão dos Santos ${ }^{3}$. Roberto da Justa Pires Neto $^{4}$.

1 Estudante de Medicina, Faculdade de Medicina, Universidade Federal do Ceará, Fortaleza, Ceará, Brasil. 2 Mestre em Doenças Infecciosas e Parasitárias, Médica do Hospital São José de Doenças Infecciosas e Secretaria de Saúde do estado do Ceará, preceptora do Serviço de Infectologia do Hospital Universitário Walter Cantídio, Universidade Federal do Ceará, Fortaleza, Ceará, Brasil. 3 Especialista em Doenças Infecciosas, Enfermeira, Mestranda do Programa de Pós-Graduação em Saúde Pública, Faculdade de Medicina, Universidade Federal do Ceará, Fortaleza, Ceará, Brasil. 4 Doutor em Medicina, Médico do Hospital São José de Doenças Infecciosas e Secretaria de Saúde do estado do Ceará, Professor de Infectologia pelo Departamento de Saúde Comunitária e Programa de Pós-Graduação em Saúde Pública, Faculdade de Medicina, Universidade Federal do Ceará, Fortaleza, Ceará, Brasil.

\begin{abstract}
Severe imported malaria is a clinically significant problem in non-endemic areas. We report two cases of travelers with Plasmodium falciparum infection who traveled from Africa and came home to a Brazilian non-endemic region. The epidemiology and diagnostic aspects of severe imported malaria for travel medicine clinicians in non-endemic regions are reviewed.
\end{abstract}

Palavras-chave: Malaria. Malaria, falciparum. Travelers' health.

\section{RESUMO}

Malária grave é uma condição clinicamente importante em regiões não endêmicas da doença. Relatamos dois casos de viajantes com infecção grave por Plasmodium falciparum que viajaram para a África e retornaram a uma região não endêmica do Brasil. Foi feita uma revisão acerca da epidemiologia e dos aspectos diagnósticos da malária grave importada como alerta aos profissionais sobre saúde do viajante.

Keywords: Malária. Malária falciparum. Saúde do viajante.

Corresponding author: Roberto da Justa Pires Neto, Departamento de Saúde Comunitária, Universidade Federal do Ceará, Rua Papi Junior, 1223, $5^{\circ}$ andar, Rodolfo Teófilo, Fortaleza, Ceará. CEP: 60430-140. Telefone: +55 85 3366-8044. E-mail: robertojusta@ufc.br

Conflict of interests: Não há qualquer conflito de interesses por parte de qualquer um dos autores.

Recebido em: 03 Jun 2018; Revisado em: 23 Ago 2018; Aceito em: 26 Ago 2018. 


\section{INTRODUCTION}

Malaria is a parasitic disease transmitted by Anopheles mosquitoes and clinically characterized as a febrile syndrome. It is endemic in about 90 countries and represents a real threat to life. ${ }^{1}$ The main species that can cause disease in humans are Plasmodium vivax, P. falciparum, P. malariae, P. ovale, and $P$. knowlesi. However, the first two species are more relevant on a global scale as they are responsible for most cases. ${ }^{2}$

The clinical spectrum of the disease is quite broad, ranging from vague symptoms such as fever, headache, and abdominal discomfort to severe conditions. Severe malaria is characterized by changes in consciousness, respiratory failure, seizures, prostration, circulatory shock, pulmonary edema, abnormal bleeding, jaundice, severe anemia, hypoglycemia, acidosis, hyperlactatemia, acute kidney injury (AKI), or hyperparasitemia, and is mainly caused by P. falciparum. ${ }^{2,3}$

In Brazil, malaria is an endemic disease in the Amazon region, with $>100,000$ cases reported annually. Most cases in this setting are caused by $P$. vivax. Other regions of the country, including the state of Ceará located in the northeast, are considered non-endemic regions, and the reported cases tend to be imported from endemic regions in the Brazilian Amazonia or from other endemic countries. ${ }^{4,5}$

The management approach of malaria in Brazilian non-endemic regions is especially challenging for health teams, due to the plethora of differential diagnoses with acute febrile syndrome, especially arbovirus infections. This fact may contribute to an unfavorable evolution of the disease and its potential progression to severe malaria and death. ${ }^{4,5}$ We present two cases of severe malaria admitted at a referral hospital for infectious diseases in Fortaleza, Ceará, Brazil.

\section{CASE REPORT 1}

A 24-year-old man from Angola recently arrived in Brazil in April 2015 to study at a university in the state of Ceará. Five days after his arrival, he was brought to an emergency service, with a history of fever, malaise, headache, generalized myalgia, and darkening of the urine color for 3 days. During the last $24 \mathrm{~h}$, he presented with mental confusion and decreased level of consciousness.

During the physical examination, the main findings were tachycardia, tachypnea, and jaundice $(++)$. Considering the potentially serious situation, the patient was referred to a reference hospital for infectious diseases. In this unit, the possibility of dengue, malaria, and leptospirosis was suspected and investigated. Laboratory tests upon admission (Table 1) revealed anemia, leukocytosis, thrombocytopenia, mild increase in liver transaminases, and hyperbilirubinemia. Direct investigation for Plasmodium $s p$. in the peripheral blood sample revealed $P$. vivax $(+)$ and $P$. falciparum $(++++)$ coinfection. Specific treatment for coinfection was initiated with clindamycin and artesunate.

During the first $24 \mathrm{~h}$ of hospitalization, the patient developed respiratory insufficiency and was admitted to an intensive care unit for mechanical ventilation. He then developed metabolic acidosis (pH 7.29), hemodynamic instability, renal dysfunction, and pulmonary edema. The initial antimalarial treatment was suspended on the 7th day of hospitalization, and primaquine was prescribed for another 7 days. The patient presented with improved clinical and laboratory results and was transferred to the ward on the ninth day. He recovered uneventfully and was discharged on the 15th day. Outpatient follow-up showed negative tests for Plasmodium sp. in the peripheral blood sample on four subsequent occasions.

Table 1. Results of laboratory tests requested upon admission of two severe cases of malaria in Fortaleza, Ceará, Brazil.

\begin{tabular}{lcc}
\hline \multirow{2}{*}{ Laboratorial exam } & \multicolumn{2}{c}{ Results } \\
\cline { 2 - 3 } & Case 1 & Case 2 \\
\hline Hematocrit (\%) & 20,9 & 28.9 \\
White blood cells (/mm $\left.{ }^{3}\right)$ & 15,330 & 9,800 \\
Platelets (/mm $\mathbf{m}^{3}$ & 17,000 & 556,000 \\
AST (IU/L) & 228 & 58 \\
ALT (IU/L) & 106 & 93 \\
Total bilirubin (mg/dL) & 6.72 & 0.12 \\
Direct bilirubin (mg/dL) & 8.01 & 0.22 \\
\hline
\end{tabular}

AST: aspartate aminotransferase; ALT: alanine aminotransferase.

\section{CASE REPORT 2}

A 20-year-old man from Quixadá, a small city in the state of Ceará, Brazil, was on a humanitarian mission in Africa for at least 3 months. He returned to Brazil in October 2017 after having an acuteillness. The patient becameill in Guinea-Bissau, initially presenting with fever $\left(40^{\circ} \mathrm{C}\right)$ and diarrhea associated with headache, adynamia, and decreased appetite. He sought medical assistance, and was diagnosed with typhoid fever (positive Widal reaction), which was initially treated with oral ciprofloxacin. Despite this treatment, his fever, nausea, vomiting, and moderate-intensity abdominal pain persisted, which caused him to seek further medical attention. This time, he was hospitalized, and antibiotic therapy with

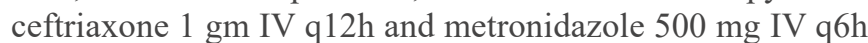
was initiated, in addition to other symptomatic medications. After 3 days of hospitalization, he developed digestive bleeding (hematemesis and hematochezia), temporary loss of consciousness, and hypotension $(70 / 50 \mathrm{mmHg})$. Laboratory examinations showed anemia, with low hemoglobin level (3.7 g/dL).

After some clinical improvements, he was transferred to Brazil and referred to a reference hospital for infectious diseases in Fortaleza, Ceará. Upon arrival, laboratory tests 
showed anemia, thrombocytosis, and slightly elevated hepatic transaminases (Table 1). P. falciparum was detected during a rapid test for malaria. Direct investigation for Plasmodium $s p$. in the peripheral blood was positive for $P$. falciparum $(+++)$. Serologies for syphilis, hepatitis B and C, and human immunodeficiency virus were negative. Upper gastrointestinal endoscopy showed two ulcers in the posterior wall of the stomach, one healed and another active, each measuring approximately $8 \mathrm{~mm}$. Treatment with artesunate and clindamycin was initiated, in addition to ceftriaxone due to the coexistence of typhoid fever. The patient recovered and was discharged after 10 days of hospitalization.

\section{DISCUSSION}

We report the cases of two young men arriving from Africa to Brazil with acute severe infectious diseases that progressed with various complications. In both situations, malaria was confirmed through the presence of Plasmodium $\mathrm{sp}$. on the peripheral blood smear. The first case presented with disturbed consciousness, respiratory insufficiency, jaundice, severe anemia, acidosis, and AKI. The second case showed changes in consciousness, circulatory shock, abnormal bleeding, and severe anemia. These manifestations allow both cases to be classified as severe malaria according to the World Health Organization (WHO) criteria. $^{3}$

Severe malaria is an entity most reported in the pediatric age group, particularly affecting children aged $<5$ years in sub-Saharan Africa. However, this premise is not applicable to low or non-endemic regions, where severe malaria is equally distributed in adults and children. ${ }^{3}$ Globally, the incidence of severe malaria is low. In Brazil, the proportion of malaria cases requiring hospital admission is approximately $1.3 \%{ }^{6}$ However, in non-endemic areas, mainly due to the lack of previous immunity of the inhabitants and delayed diagnosis, this rate increases, and the occurrence of severe malaria in all age groups becomes a real concern. ${ }^{5-7}$

The presence of mixed $P$. vivax and $P$. falciparum infections and the clinical course with several complications are the main aspects that need attention in the first case. Studies

\section{REFERENCES}

1. World Health Organization. Fact sheet about Malaria [Internet]. Geneva: World Health Organization; 2017 [cited: 3 nov 2017]. Avaliable: http://www.who.int/mediacentre/ factsheets/fs094/en/

2. White N, Pukrittayakamee S, Hien T, Faiz M, Mokoulu O, Dondorp A. Malaria. Lancet. 2014;383(9918):723-35.

3. World Health Organization. Severe malaria. Trop Med Int Health. 2014;19(Suppl 1):7-131.

4. Nascimento JA, Guimarães LM, Carvalho-Costa FA. Malaria epidemiology in the State of Piauí, Northeastern Brazil: a retrospective study with secondary data. Rev Soc Bras Med Trop. 2016;49(1):99-103. that compare the clinical and laboratory aspects between $P$. vivax or $P$. falciparum single infection and double infection suggest that coinfection is associated with different outcomes, including a lower probability of developing complications. ${ }^{8,9}$

The biological interaction between different species of Plasmodium and their clinical repercussion are not well established. However, some studies reported the possibility of parasitemia suppression during the concomitant existence of $P$. vivax and $P$. falciparum. ${ }^{9}$

In the second case, a positive serology for typhoid fever and the use of antibiotic (ciprofloxacin) with reduced efficacy against $P$. falciparum immediately after the onset of symptoms probably contributed to delayed malaria diagnosis. Previous studies attested that quinolones are potent against $P$. falciparum. However, its mode of action against Plasmodium species is still unknown, and the relatively slow antimalarial action of fluoroquinolones limits their clinical application in treating $P$. falciparum malaria. ${ }^{10}$

The WHO recommends that artesunate should be the drug of choice in the treatment of severe malaria caused by both $P$. falciparum and $P$. vivax. A primaquine course is also indicated after remission of symptoms in $P$. vivax infections. ${ }^{6,11}$

In addition to the use of specific antimalarial drugs, severe malaria requires effective monitoring and supportive therapy to limit potential complications. The most frequent complication in patients with severe malaria requiring intensive care assistance is AKI, followed by acute respiratory distress syndrome..$^{6,12}$

The reported cases illustrate the challenges in approaching severe malaria in non-endemic regions. Health professionals' inexperience in the management of severe malaria cases, $P$. vivax and $P$. falciparum coinfection, and possible coinfection with other microorganisms as confounding factors in the approach of travelers coming from malaria-endemic regions justify the relevance of the cases reported and alert the need for surveillance of severe imported cases of malaria that may occur in Brazilian non-endemic regions.

5. Costa A, Bressan C, Pedro R, Valls-de-Souza R, Silva S, Souza $\mathrm{P}$, et al. Diagnóstico tardio de malária em área endêmica de dengue na extra-Amazônia Brasileira: experiência recente de uma unidade sentinela no estado do Rio de Janeiro. Rev Soc Bras Med Trop. 2010;43(5):571-4.

6. Ministério da Saúde. Guia prático de tratamento da malária no Brasil. Brasília: Ministério da Saúde; 2010.

7. Dos-Santos JC, Angerami RN, Castiñeiras CM, Lopes SC, Albrecht L, Garcia M, et al. Imported malaria in a non-endemic area: the experience of the university of Campinas hospital in the Brazilian Southeast. Malar J. 2014;13:280.

8. Mitra S, Abhilash K, Arora S, Miraclin A. A prospective study 
from south India to compare the severity of malaria caused by Plasmodium vivax, P. falciparum and dual infection. J Vector Borne Dis. 2015;52(4):281-6.

9. Mayxay M, Pukrittayakamee S, Newton PN, White NJ. Mixed-species malaria infections in humans. Trends Parasitol. 2004;20(5):233-40.

10. World Health Organization. Guidelines for the treatment of malaria. 3. ed. Geneva: WHO; 2015.
11. Watt G, Shanks G, Edstein M, Pavanand K, Webster HK, Wechgritaya S. Ciprofloxacin treatment of drug-resistant falciparum malaria. J Infect Dis. 1991;164(3):602-4.

12. Marks M, Armstrong M, Walker D, Doherty T. Imported falciparum malaria among adults requiring intensive care: analysis of the literature. Malar J. 2014;13:79.

\section{How to cite:}

Rocha MD, Girão ES, Santos JR, Pires RJ Neto. Severe imported malaria in a Brazilian non-endemic region: a permanent alert for travelers and health teams. Rev Med UFC. 2019 jan-mar;59(1):71-74. 